\title{
動脈瘤を伴う脳動脈分岐部まわりの非ニュートン流体解析*
}

\author{
船 㟝健 一*1, 山田 和 豊*1, 中村 豪*2
}

\section{Numerical Simulation of Non-Newtonian Blood Flow Near a Cerebrovascular Branch with an Aneurysm}

\author{
Ken-ichi FUNAZAKI*3, Kazutoyo YAMADA and Goh NAKAMURA \\ ${ }^{* 3}$ Department of Mechanical Engineering, Iwate University, \\ 4-3-5 Ueda, Morioka-shi, Iwate, 020-8551 Japan
}

\begin{abstract}
This study deals with numerical simulation performed on pulsatile blood flow near a typical cerebrovascular branch with an aneurysm. Non-Newtonian properties of the blood is taken into account in this simulation by use of Carreau-Yasuda viscosity model. The aneurysm concerned takes the shape of sphere, this simple geometry being chosen for the sake of wide range of parametric studies. The numerical studies using a commerical solver CFX-5 (ANSYS), which employs unstructured grid system with clustering of prism-type elements near the cerebrovascular artery and aneurysm walls, reveal the important effects of several parameters such as aneurysm angle or bifurcation flow ratio upon magnitude of wall shear stress and its gradient on the wall. Besides, an attempt is also made using several models of the aneurysm with different sizes to clarify how and to what extent the appearance of the aneurysm changes the flow field around the bifurcation without aneurysm
\end{abstract}

Key Words: Aneurysm, Blood Flow, Cerebrovascular Arteries, Numerical Simulation, NonNewtonian Fluid

\section{1. 错}

脳卒中の一つで致死率の高いくも膜下出血は, 脳 動脈瘤の破裂が主な原因である. 近年, 3-D CT スキ ヤン, MRA 等の機器の普及により未破裂状態の脳動 脈瘤の発見は可能になってきたが，発見された瘤の破 裂の可能性に関しては, 瘤のサイズ以外に判断する指 標はないに等しい. また, 手術する場合にも, それに 伴うリスクが高く, 手術した人の $5 \%$ が後遺症を引き 起こすといわれている(1). 従って, 瘤は発見したが手 術するかどうかの高度な判断が患者に委ねられている のが現状である.

現在までに脳動脈瘤に関する研究は数多く行われ ているが, 瘤の成長や破裂には物理的要因と生理学的 要因が関係しており, 成長や破裂に至るまでのメカニ ズムは明確には解明されていない. 氏家(1)は，脳動脈 瘤の形成過程に関して以下の仮説を立てている.

脳動脈が分岐する地点で大きなせん断応力が血管 壁に作用し，それを誘発要因として血管壁に focalized angiogenesis（局所的血管新生）が生じ動脈の膨らみ が発生する.この膨らみは，引き続き作用する高せん 断応力によって増大し, 流れの慣性力によって円形に 成長する.この部分が一定以上に膨らみ動脈瘤となっ た後は，この瘤が盲端であるため瘤内の流れは遅くな

* 原稿受付 2005 年 4 月 18 日.

*1 正員, 岩手大学工学部(画 020-8551 盛岡市上田 4-3-5)

*2 准員, フルーエント・アジアパシフィック (株) (五 160-0023 東京都新宿区西新宿 6-10-1)

E-mail : funazaki@iwate-u.ac.jp
り，血管壁に作用するせん断応力は著しく減少する. これに伴って血管壁には動脈硬化に類似した angioregression（血管退行）が生じると考えられる. 血管壁の退行変行そして流れの停滞による凝固能の立 進は，最終的に matrix metalloprotease 等の蛋白分解酵 素の活性化を促進し，壁の浸食を導き破裂に至る.

以上のように, 動脈瘤の発現, 成長, 破裂には, 血流の状態とそれにより生ずる血管壁上のせん断応力 及びそれを誘発因子とする血管細胞の生理学的挙動が 複雑に関与している. この問題への血流力学的な取り 組みとしては，血管壁上のせん断応力を詳細に把握す ることが重要となる. 近年, MRI などから実際の瘤 形状を抽出し，血液や血管の特性や血管のリアリステ イック形状を追求した数值解析の研究(2) (3)LDVな どの非接触法での計測例(5)（6) が増えてきている. しか し，実形状での解析からは動脈瘤での流れ場に共通す る現象の抽出は容易ではない. 従って, 本研究のよう な動脈瘤の簡易化モデルを用いた基礎的研究も，動脈 瘤まわりの血流力学的特徴を理解する上で有益である と考えられるが，このような基礎的研究の多くは実験 的研究(7)(9にとどまっている.

著者の 1 人(10は，実際の動脈瘤を参考にガラスの Y字分岐管に球形の動脈瘤状の膨らみを持たせ，分岐 部近傍での流れを観測した. 川口(11)は実験で用いたモ デルを元に, 動脈瘤近傍の流れの数值シミュレーショ 
ンを行った. 本研究はこれらの研究を発展させ, 球形 脳動脈瘤モデルを利用して, 拍動流や流体の非ニュー トン性, 分岐での流量比や瘤の幾何学形状がどのよう に瘤内部での流れに影響を与えるかを，主に動脈瘤の 壁面せん断応力（W.SS.）や壁面せん断応力勾配 (W.S.S.G.) などに着目しながら，流れの数值シミュ レーションによって明らかにした. また, 数種類の大 きさの瘤モデルを分岐部に設け，これらの瘤が分岐部 近傍における W.S.S.等をどのように変化させるかを調 查した.

Table1 Flow analysis conditions

\begin{tabular}{|c|l|}
\hline Boundary Conditions & $\begin{array}{l}\text { Inlet: velocity profile specified } \\
\text { (paraboloid of revolution) }\end{array}$ \\
\hline & Outlet: flow rate fixed \\
\hline & Wall : non-slip \\
\hline Blood Properties & Viscosity : Carreau-Yasuda model ${ }^{(12)}$ \\
\hline & Density $: 1.05 \mathrm{~g} / \mathrm{cm}^{3}$ \\
\hline & Reference Pressure: $0 \mathrm{~Pa}$ \\
\hline & $10^{-2} \mathrm{~s}$ \\
\hline
\end{tabular}

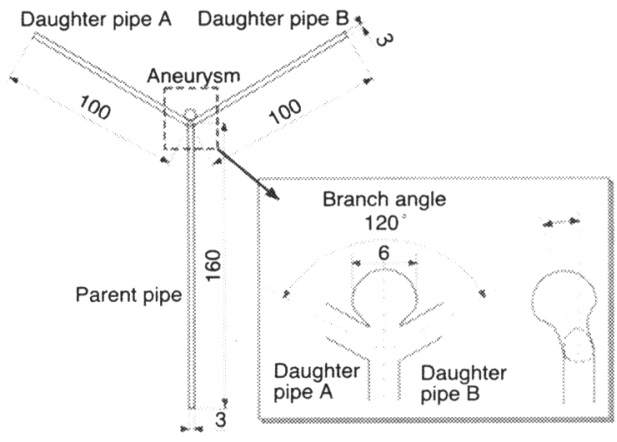

Fig. 1 Schematic of aneurysm model

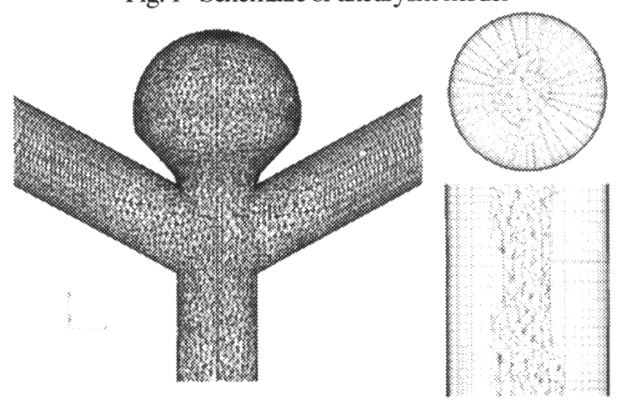

Fig.2 Mesh system for blood flow analysis

\section{2. 計算 モ デル}

本研究で使用した計算モデルを図 1 に示す.この モデルは，1本の親管と $\mathrm{Y}$ 字状に分岐した 2 本の娘 管 $\mathrm{A}, \mathrm{B}$ 及び分岐部に存在する球形の瘤から構成され ている，瘤直径は，脳動脈瘤の実例を元に $6 \mathrm{~mm}$ とし た(11).アスペクト比（奥行きと開口部直径との比）は, 破裂しやすい動脈瘤のアスペクト比が 1.6 以上である
という知見(1)を参考にして，その值を 2 とした，血管 直径は簡単のため親管, 娘管とも $3 \mathrm{~mm}$ とし, 分岐角 度は $120^{\circ}$ である. 分岐部での血流場への入口部及び 出口部の影響を極力避けるため，親管及び娘管の長さ をそれぞれ血管直径の約 54 倍 $(160 \mathrm{~mm})$ 及び約 34 倍（100 mm）とした．また，親管・娘管の管軸がな す平面（以後分肢管平面という）と瘤回転軸との間の 角度（以後瘤角度と呼ぶ）に関しては，4種類の瘤角 度 $\left(0^{\circ} ， 15^{\circ} ， 20^{\circ}\right.$ 及び $\left.30^{\circ}\right)$ を調査した. 娘管 $\mathrm{A}$, Bの分岐流量比は1：1及び2：1の二通りである.

図 1 に示寸計算モデルを 3 次元 $\mathrm{CAD}$ で作成した後, 非構造格子生成ソフト ICEM CFD (ANSYS) で CAD デ 一タを読み込み，図2のような格子を生成した，節点 数は約 130 万，要素数は約 298 万である. 壁近傍の 流れを精度良く捕らえるため, 壁近傍にはプリズム要 素を使用した。非構造格子を用いた場合，要素数が不 十分な場合や壁近傍での要素の選択が適切ではないと きに，円管に一様流入するニュートン流体の流れが八 ーゲン・ポアズイユ流れにまで十分に発達できないこ と，また，入口速度分布に回転放物面を指定した場合 にもその分布形状を維持できないことを経験している (13).この点を格子生成の際に十分配慮し，図 2 に示す 計算格子を作成した。この計算格子を用いてニュート ン流体の流れを解いた場合，親管入口部での一様流れ が，分岐部手前で回転放物面を有する速度分布に発達 することを確認している.

\section{3. 解 析 手 法}

汎用流体解析ソフト CFX5.6 (ANSYS) を用いて, 非定常非圧縮非ニュートン流体解析を行った．乱流モ デルは使用していない! 計算機は岩手大学総合情報処 理センターの origin3800（sgi）を利用した. 解析条件 を表 1 に示す. 流入条件として拍動する血流速度を与 えた. 速度の時間的変化パターンとして, 鳥井らひ よって得られた 20 代男性頚動脈での流速波形 1 周期 分を採用した（図 3 ）。入口速度分布には，十分に発 達した流れとして, 各瞬間において平均速度が図 3 で の速度に一致する速度分布（回転放物面）を与えた. 非定常計算の時間ステップは $10^{2} \mathrm{~s}$ とした. 非定常計 算を行う前に，0 sにおける拍動流速度を流入速度と して定常計算を行い，それを初期值とした．各時間ス テップ毎の最大繰り返し回数を 10 回とし, 最大残差 が $10^{-4}$ を下回ったとき収束したとみなした.

血液の非ニュートン性を考慮するため, CarreauYasuda 粘度モデルを採用した. このモデルでは，粘 性係数 $\mu$ 法次のように与えられる(12). 


$$
\mu(\dot{\gamma})=\mu_{\infty}+\frac{\mu_{o}-\mu_{\infty}}{\left(1+(\lambda \dot{\gamma})^{b}\right)^{a}}
$$

$\mu_{o}: 1.6 \times 10^{-1} \mathrm{~Pa} \cdot \mathrm{s}, \mu_{\infty}: 3.5 \times 10^{-3} \mathrm{~Pa} \cdot \mathrm{s}$ $a: 1.23, b: 0.64, \lambda: 8.2 \mathrm{~s}$

式(1)中の指数や倸数はへマトクリット值 $45 \%$ の血液 に対応する值である．また $\dot{\gamma}$ はひずみ速度で，ひず み速度テンソル $\mathbf{e}=\left\{\varepsilon_{i j}\right\}$ を用いた次式で計算される.

$$
\dot{\gamma}=\sqrt{2 \varepsilon_{i j} \varepsilon_{i j}}, \quad \varepsilon_{i j}=\left(\partial u_{i} / \partial x_{j}+\partial u_{j} / \partial x_{i}\right) / 2
$$

式(1)で計算される粘性係数とひずみ速度との関係を 図 4 に示す．脳動脈の血流のひずみ速度は $100 \mathrm{~s}^{-1}$ を大 きく上回ることが普通であり(，その場合図 4 から明 らかな様に，一般にはニュートン流体として扱うこと になるが, 動脈瘤を伴う場合, 瘤内での流れのよどみ 状態発生が予測され，ひずみ速度低下に伴う非ニュー トン性の発現が想定される.

本研究では, 以下の式(3)で定義される壁面せん断 応力(W.S.S)の大きさ $\left|\tau_{w}\right|$ と $\tau_{w}$ の空間的勾配(W.S.S.G.) の大きさ $\left|\nabla \tau_{w}\right|$ を用いて，血流場を評価した.

$$
\tau_{w}=2 \mu \mathbf{e} \cdot \mathbf{n}_{w}
$$

ここで， $\mathbf{n}_{w}$ は壁面での法線ベクトルである. W.S.S.G. については，内皮における浸透率への影響などを通じ て血管壁肥大 (hyperplasia) 発現の仲介役を担うなど の可能性を示唆する研究(14)゙ある一方で, 上記の可能 性を否定する研究(15)もりり，WS.S.G.が流れによる血 管損傷の可能性に関する指標として有効であるかの評 価は定まっていない. 本研究では, 参考のため主な計 算事例において算出している.

\section{4. 結 果と考察}

基準モデル 以下では主に動脈虜内の流れの挙動と 壁面せん断応力分布及ひ壁面せん断応力公配について 議論する. その際, 図 3 で示した 1 拍動間での速度変 動の内，図中の 4 つ速度位相における結果について の比較検討を行う。この4つの位相とは，(1)加速開始 時(経過時間 $0.02 \mathrm{~s}$ ) (2)最大速度到達時(経過時閒 $0.1 \mathrm{~s}$ ) (3)减速時(経過時間 $0.22 \mathrm{~s}$ ) (4)極小速度到達時 $(0.33 \mathrm{~s})$, である. 1 拍動間における管路直径及び平均流速に基 づくレイノルズ数は，おおよそ 180-630 である（粘 性係数は式(1)の $\mu_{\infty}$ を使用).

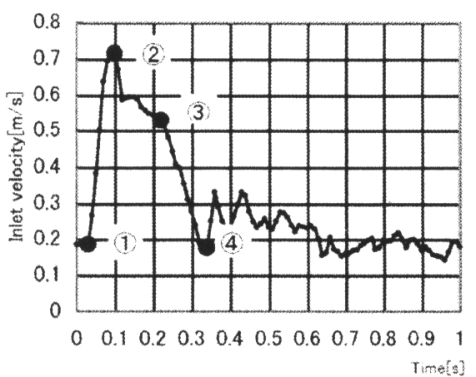

Fig.3 Velocity variation of pulsatile flow

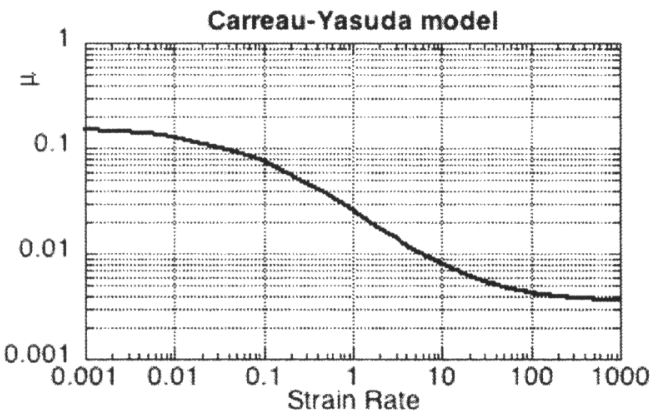

Fig. 4 Viscosity variation with strain rate calculated by Carreau-Yasuda model.
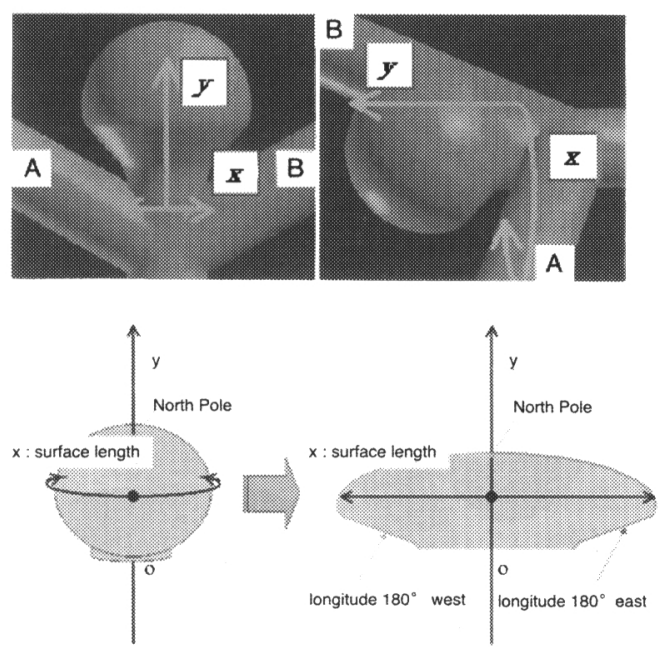

Fig. 5 Inner surface development of the aneurysm model

計算結果の可視化, データマイニング等には FIELDVIEW(Intelligent Light)を用いた。また，瘤の内 面上での W.S.S.分布及び W.S.S.G.分布を平面的に示す ため，図 5 に示すように瘤内面の展開図を用いた。こ れについて説明する。まず，分岐管平面に対して重直 で親管軸を含む平面と瘤表面との交差線を求める. 親 管と反対側にある瘤天頂（地球の北極に相当）から瘤 上面交差線（経度 0 度に相当）にそって瘤入口部まで 
を分岐管平面に投影し，y 軸とする．瘤上面交差線か ら左右の経度方向に瘤下面交差線（西経 180 度及び東 経 180 度に相当）までの表面長さを求め，y軸を対称 軸として左右に表面長さを取ることで図 5 のような展 開図を得る. 図中, $\mathrm{x}$ 軸は $\mathrm{y}$ 軸からの距離, 即ち瘤表 面上の距離となる.

図6の各図の左側には, 瘤角度 0 度, 分岐流量比 1:1 の場合の WS.S.G.及び流線を，4つの位相につい て表す。この図で左側に半透明に見えている部分が瘤 モデル表面で，その内部に流線を示す，また瘤の表面 には W.S.S.G.のコンターを示す。また，図6の右側に は展開図上のWS.S.及びW.S.S.G.を示す.

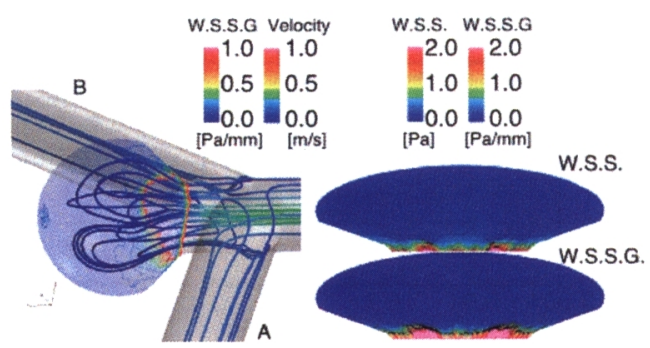

(1)Streamline,W.S.S. and W.S.S.G. $(t=0.02 \mathrm{~s})$
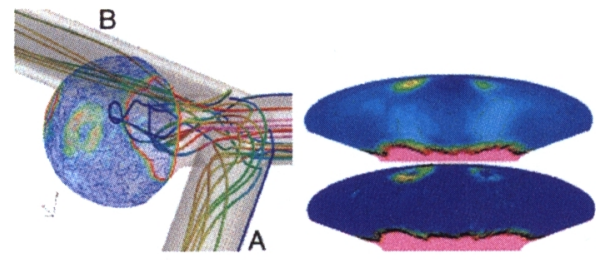

(2) Streamline,W.S.S. and W.S.S.G. $(t=0.1 \mathrm{~s})$
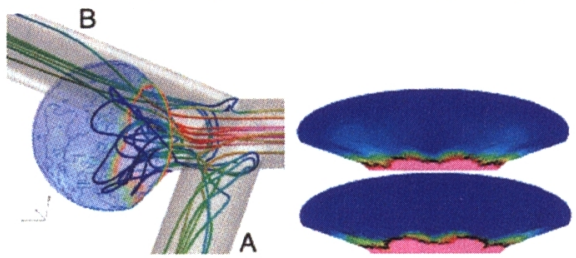

(3) Streamline,W.S.S. and W.S.S.G. $(t=0.22 \mathrm{~s})$
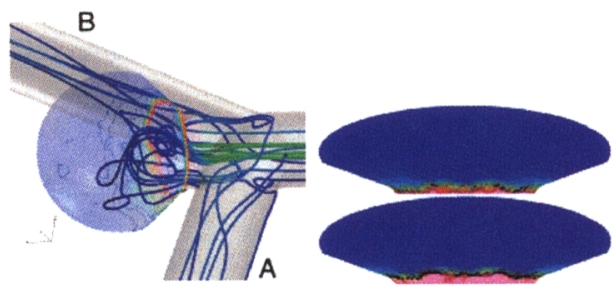

(4) Streamline, W.S.S. and W.S.S.G. $(t=0.33 \mathrm{~s})$

Fig.6 Instantaneous contours of shear stress characteristics on the model surface and streamlines(bifurcation flow rate 1:1)
図 6 (1)の加速開始直後では，親管からの血流の一 部は瘤内部一流入した後, 瘤内壁面に沿って流出し, 分岐管へと分かれていく.この一連の流れ挙動により， 瘤根元部で WSS.G.の増加を招いている. WSS. も瘤 展開図より，その部位で増加が示されている. 図 6 (2) の最大速度到達時には, 血流が塯の根元から遠位部ま て侵入し天頂部に衝突し，W.S.S.と W.S.S.G.の増加を もたらしている. 発生した W.S.S.の分布は必ずしも上 下対称ではなく, 経度 0 度側に流れが若干偏在してい る. 最大速度到達後，(3)，(4)で次第にせん断力は瘤根 元部に限定されるようになり, 瘤内の流れもほほ停滞 状況となったことがわかる.

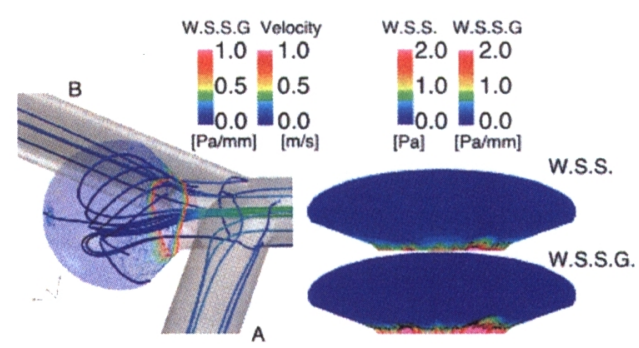

(1) Streamline,W.S.S and W.S.S.G. $(\mathrm{t}=0.02 \mathrm{~s})$
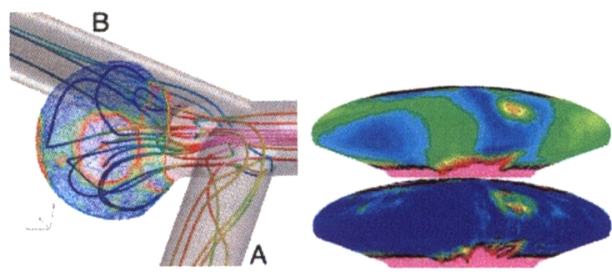

(2) Streamline, W.S.S .and W.S.S.G. $(t=0.1 \mathrm{~s})$
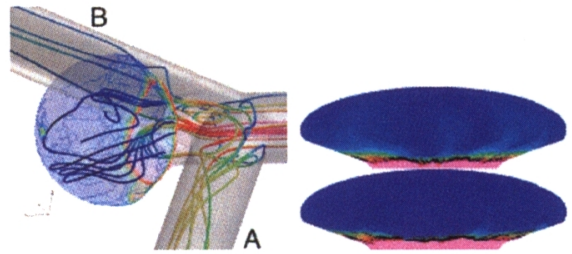

(3) Streamline,W.S.S .and W.S.S.G. $(t=0.22 \mathrm{~s})$
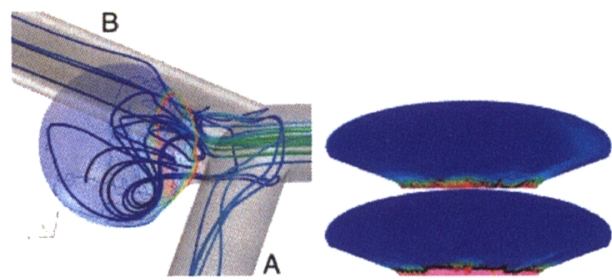

(4) Streamline,W.S.S and W.S.S.G. $(t=0.33 \mathrm{~s})$

Fig.7 Instantaneous contours of shear stress characteristics on the surface of the model and streamlines ( bifurcation flow rate 2:1) 
分岐流量比の影響 氏家(は, 脳動脈瘤の破裂に与 える分岐流量比の影響を指摘した. そこで, 以下に分 岐流量比の効果を検討する.

図 7 に娘管A，Bの分岐流量比 2:1 の場合の結果を 示す. 加速開始時（1) において, WSS.と WSS.G. の分布は基淮モデルと似ているが，最大速度達成時(2) において, 流量の多い娘管A側の根元側から流体が瘤 内に流入することにより, 瘤内の流れ構造は基準モデ ルの場合と大きく異なってくる. WSS.分布より, 瘤 左側（娘管A側）から流入した血流は，瘤天頂部に比 較的高いせん断応力を発生し, その後瘤の経度 0 度近 傍及び東経 $180^{\circ}$ よりやや右側に高せん断応力領域を 引き起こしていることが分かる. W.SS.G.の分布でも 瘤右側 (娘管B側) 一の血流の影響が顕著に現れてい る. その後急速に瘤内の流れは停滞していく. 図8に は, 瘤内面展開図上での平均 WSS.の時間的変化を示 す. 分岐流量比 21 での平均 WSS は, 流量比 $1: 1$ で の結果よりも全体的に増加しており, ピーク值で比較 すると $25 \%$ 程度もの増加が確認できる.

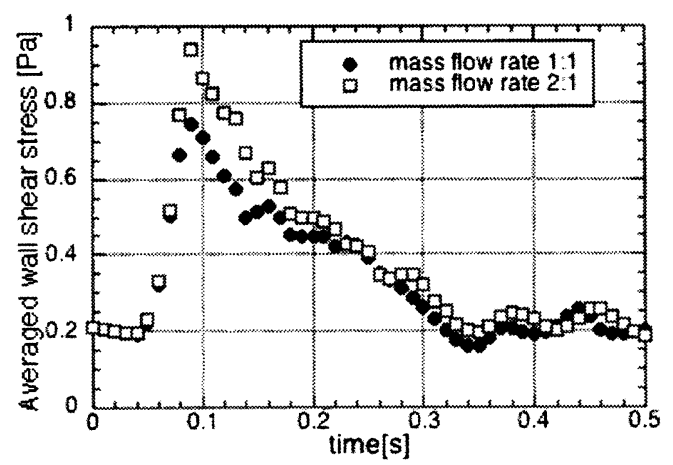

Fig. 8 Effect of bifurcation flow rate on averaged W.S.S.

嘴角度の影響 瘤角度 30 度のモデルに対して, 流 量比 1:1 の場合の解析結果を図 9 に示す. 加速開始時 (1)及び極小速度到達時(4)で, 瘤根元部近傍で再循環領 域と見なせる流れの挙動が確認できる. 最大速度到達 時(2に再循環領域を避けるように瘤下部から瘤内部に 血流が押し込まれ, 瘤上部に衝突するような形で瘤内 に強い旋回流を生じている. 結果として, 瘤上部のか なり広い領域に比較的強いせん断応力を発生させてい る. この影響は减速開始後も持続し, 最低速度達成時 (4)でもしっかりと確認できる.

その他の瘤角度に対する計算結果を総合すると， 角度が大きくなることで, 瘤根元部近傍に発生する再 循環領域によるブロッケージ効果が作用し, 瘤内部一
の血流の増速を招き, 瘤上部における高 WSS 領域 の発生，拡大に繋がると考えられる.

図 10 には, 瘤内面展開図上での平均せん断応力の 時間的変化を瘤角度毎に示す. 瘤角度 0 度では, 平均 WSS は最大速度達成時(2)で最大值に到達後, 直線的 に低下している. 瘤角度 15 度では, 急激な平均 WSS.の上昇は見られないが，比較的長時間ある程度 の值が持続している. 20 度，30 度と瘤角度が増すこ とにより, WSS の值全体が大きく増加している. 原 因は明確ではないが, 瘤角度 20 度では, 比較的高い 值のWSSが長時間維持されている.

氏家の瘤破裂の仮説では, 瘤内に流れの停滞がで きると血栓化と線溶系（止血機構の最終段階で発動す る生理反応) の活性化が促進されて瘤の壁が分解され 破裂に至るといわれている( ある。程度の角度を分岐 管平面となす瘤は，その内部で緩やかな旋回が発生し やすく流れの停滞が起きにくいことから, 瘤破裂に至 る生理的反応の抑制という観点からは有利に作用する と考えることができる. 一方で, 瘤角度の影響による 高せん断力が血管壁変質を促進する可能性がある.

非ニュートン性の効果 過去の論文において, 非二 ユートン流体とニュートン流体の分岐管での挙動は, 流量比が異なると剥離領域や分岐部での壁面せん断応 力に違いが出ると報告されている(16. そこで, 動脈瘤 を伴う流れ場における非ニュートン性の効果を検討す るため, ニュートン流体を用いた計算も実施し, 非ニ ユートン流体を用いた場合の結果と比較した.

図 11 に, 最大速度達成時(2)での, 瘤表面上の W.SS.及び WSS.G.分布を示す. また，作動流体の非 ニュートン性の効果を明らかにするため, 図 12 に示 すように, 瘤表面上での平均せん断応力值の時間的変 化に関して, 流体をニュートン流体とした場合の計算 結果との比較を行った. ニュートン流体の粘性は, Carreau-Yasuda 粘度モデルにおいてひずみ速度が無 限大となった場合の值を用いた. 計算条件は, 分岐流 量比が $2: 1$ で, 瘤角度は 0 度である. 図 11 から, 二 ユートン流体の方が慮内での局所的な WSS. 值が大き く, 結果としてニュートン流体の方が平均 WSS 值 も高い. 図 12 中のピーク值での比較では, ニュート ン流体での平均せん断応力は非ニュートン流体の 30\%程度高い值を示している.このことから, 動脈瘤 内部での流れやせん断応力分布の予測には, 脳動脈の 場合でも非ニュートン流体としての解析が重要である ことがわかる. 


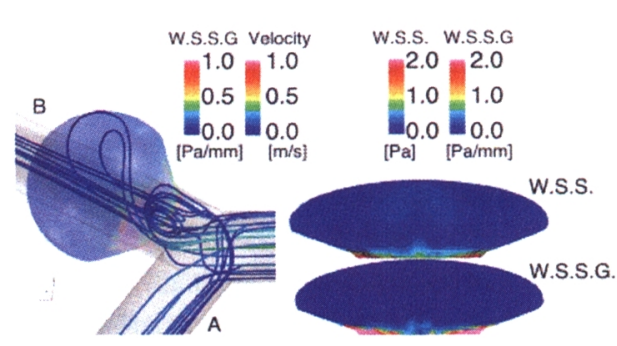

(1) Streamline, W.S.S and W.S.S.G. $(t=0.02 \mathrm{~s})$
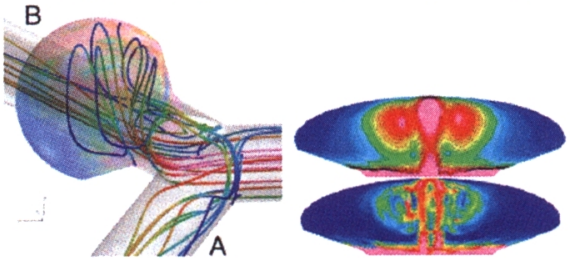

(2) Streamline, W.S.S .and W.S.S.G. $(\mathrm{t}=0.1 \mathrm{~s})$

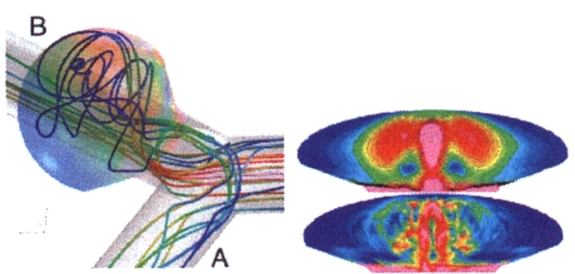

(3) Streamline, W.S.S and W.S.S.G. $(t=0.22 \mathrm{~s})$
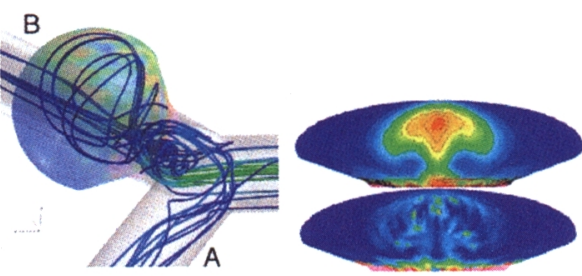

(4) Streamline,W.S.S .and W.S.S.G. $(t=0.33 \mathrm{~s})$

Fig.9 Instantaneous contours of shear stress characteristics on the model surface and streamlines ( aneurysm angle $30^{\circ}$ )

\section{5. 成長過程缯モデル}

瘤成長過程での流れ場が瘤の成長を促進するよう なせん断応力分布などをもたらすかを確認するため, 瘤の無いモデルや比較的小さな瘤モデルを有する分 岐管についての数值解析を行った（図 13）。ここ での解析では，親管と娘管の内径の関係を Murray 則(17) (親管の直径の三乗が娘管の直径の三乗の総和 に等しい）を用いて決定することで，より現実的な 分岐管モデルを対象としている.

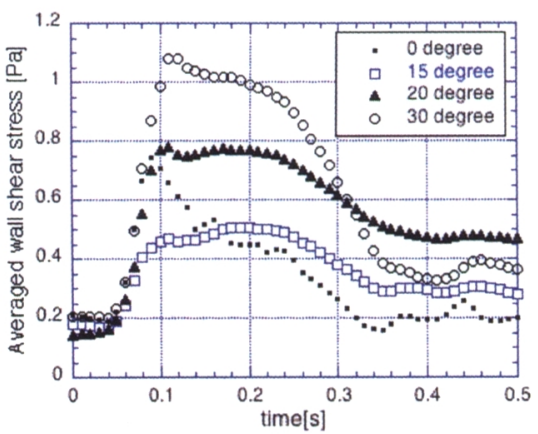

Fig.10 Temporal variations of averaged shear stress for four aneurysm angle cases (bifurcation flow rate 2: 1)

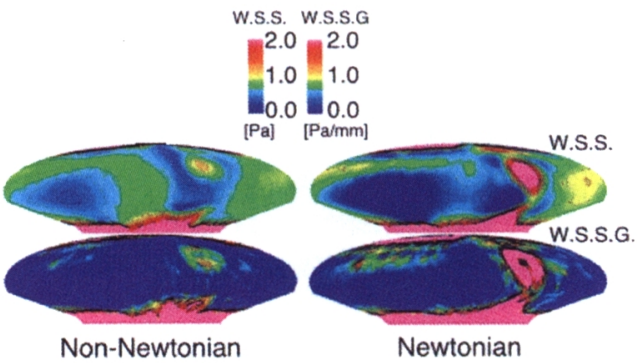

Fig.11 Difference between Newtonian fluid (right) and nonNewtonian fluid (left) in terms of W.S.S. and W.S.S.G. contours for bifurcated flow rate of $2: 1$

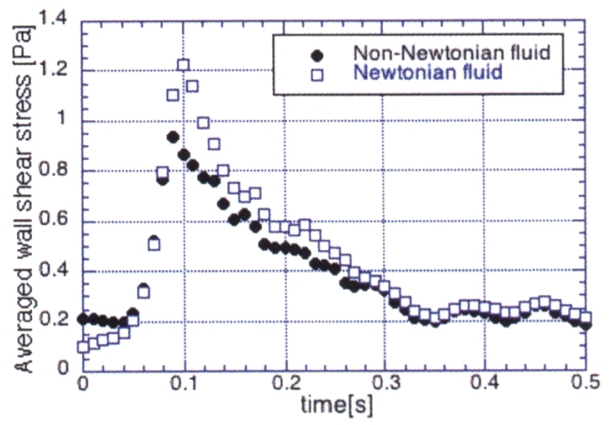

Fig.12 Time-history of averaged W.S.S. for non-Newtonian and Newtonian fluids

瘤無しモデル（Model\#1）分岐管は，親管直径 $3 \mathrm{~mm}$ とし, 分岐後の直径は Murray 則から $2.38 \mathrm{~mm}$ とした. 分岐後, 急激な管径の変化で流れの損失 を招かないようにするため，分岐部から $10 \mathrm{~mm} の$ 長さの接続区問を設けた（図 13(a)）。

球状に膨らむ瘤モデル（Mode\#\#2）＼cjkstart瘤は分岐点 (A 点)を中心として球状に成長すると仮定した。瘤 直径を3ー5 mm と変化させ瘤径の影響を調べた。 瘤の存在以外は mode\#1 と同様で, 分岐後の接続区 
間の距離は $10 \mathrm{~mm}$ とした(以下このモデルを mode\#2 とする).
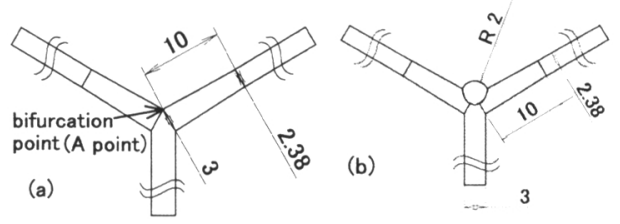

Fig. 13 Schematic of aneurysm models

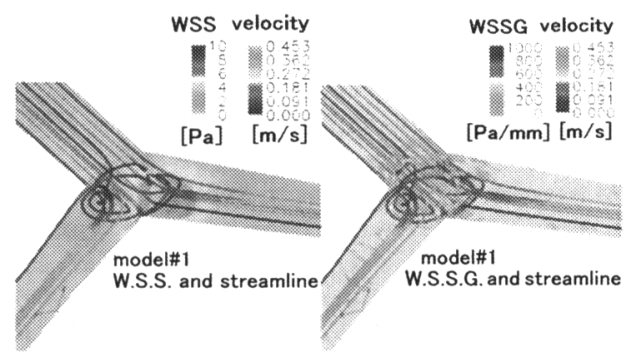

Fig.14 Streamline, WSS and WSSG distribution for modeß\#1

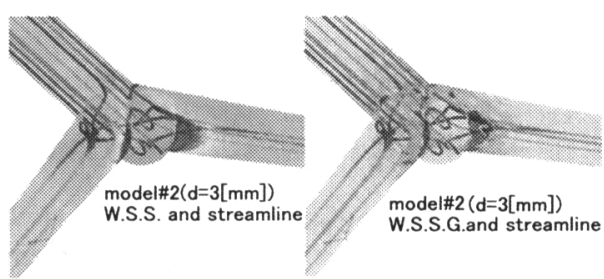

Fig.15 Streamline, WSS and WSSG distribution for model\#2 $(\mathrm{d}=3 \mathrm{~mm})$

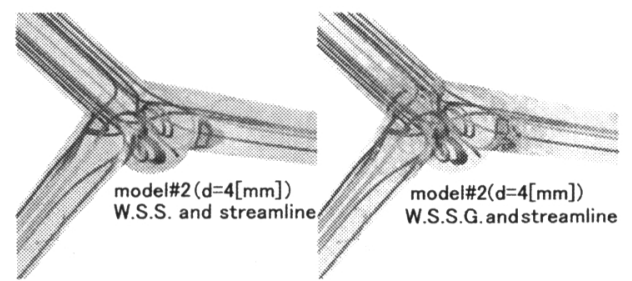

Fig.16 Streamline, WSS and WSSG distribution for model\#2 $(\mathrm{d}=4 \mathrm{~mm})$

解析条件上記のモデルを用いて，定常非ニュート ン流体解析を行った。 流体特性值は表 1 と同様である. 境界条件は, 流入条件に $0.24 \mathrm{~m} / \mathrm{s}$ の一様流を与えた。 この值は, 図 3 での流速条件での(1) (加速開始時) で の值に相当する. 分岐流量比は 1:1 とした. 壁面境界 条件はno-slip を仮定した.

結果と考察 図 14-16 に3種類の分岐管モデルに 対する血流の流線, W.S.S.分布及び W.S.S.G.分布を示 す. 図 14 に示す mode\#1 では, 通常の Y 字管と同様 に，親管からの流れが分岐管の接合部に衝突し，旋回
した後A，Bの娘管へと流れている．分岐管が接合し た点から娘管方向にかけて高せん断応力が発生し，結 果としてせん断応力の公配も大きい.

瘤径が 3mm に成長した場合 modeH2（図 15）で は，瘤根元部でW.S.S.とW.S.S.G.ともに増加してい ることがわかる。これは，親管からの流れが，瘤内 部に流入し，分岐へと向きを変化させたことと，瘤 から流出した流れの急激な増速の影響がひずみ速度 の増加を招いたためと考えられる. 瘤の径が $4 \mathrm{~mm}$ の場合（図 16）では，根元での W.S.S.やW.S.S.G.の 増加が認められ，瘤成長に寄与する現象が確認され た，図 17 には，瘤直径の変化が瘤内壁面上におけ る平均せん断応力に与える影響を示す. なお, ここ でのせん断応力值は分岐部から $5 \mathrm{~mm}$ 上流における 親管での W.S.S.の值（2.6 Pa）で無次元化されてい る.この結果から, 瘤内部での W.S.S.の平均值は, 親管での值の $65 \%$ 程度であること，調査した範囲で は瘤直径が W.S.S の平均值に与える影響は明瞭では ないが, 瘤直径 $4 \mathrm{~mm}$ の場合に平均 W.S.S が最大值 に達することなどがわかる. 非定常計算の結果では あるが図 8 との比較から，成長過程の瘤内部表面で の平均 W.S.S. $(2.6 \times 0.65=1.69 \mathrm{~Pa})$ は，発達した瘤で

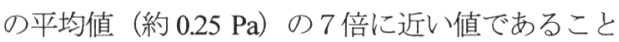
がわかる。

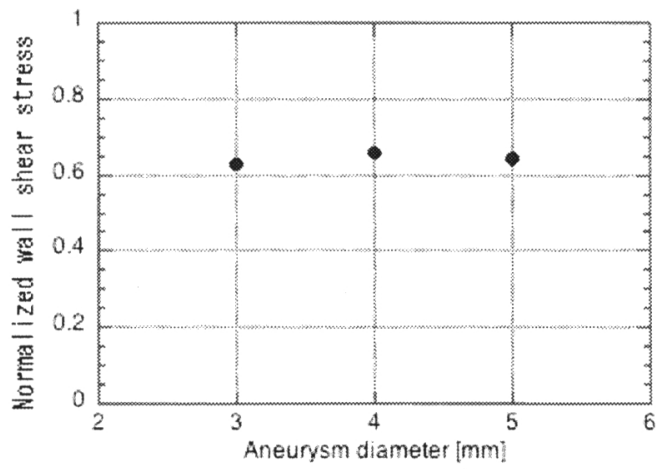

Fig.17 Effect of aneurysm diameter on averaged wall shear stress

\section{6. 結 言}

動脈瘤を伴う脳動脈分岐部まわりの非ニュートン 流解析を行なうことで，以下の知見を得た。

（1）分岐流量比は，瘤内部の壁面せん断応力やそ の空間勾配の分布に大きな影響を与える.

（2）瘤角度は, 瘤根元部における再循環領域を誘 発し, 瘤内部一の流路を狭め, 結果として流 内部一浸入する血流を加速させる. 今回調査 
した範囲では，角度が大きくなればなるほど 瘤の壁面せん断応力とその空間勾配は増加し ている.

（3）流れの停滞を生じやすい瘤内の血流場では, 非ニュートン流体はニュートン流体より淀み やすく, 結果として壁面せん断応力がニュー トン流体として解析した場合よりも小さくな る.

（4）瘤成長過程を模擬した解析の結果から，分岐 部における未発達の瘤の存在により, 瘤の根 元で壁面せん断応力やその空間勾配の值は増 加する. このことは, 分岐部でのわずかな瘤 の発生が，さらに瘤成長促進因子を強化する 可能性を示唆している.

今後は,より現実的な形状の動脈瘤モデルを用い た解析を行うとともに, 血流と動脈瘤との連成解析 などを行う予定である.

\section{剖辞}

貴重な資料のご提供をご快諾され，本研究へのご 助言もお寄せ頂いた氏家弘博士（東京女子医科大）に 感謝の意を表す.

\section{考支城}

(1) Ujiie, H., Cerebral Aneurysm and Blood Flow (in Japanese), Nihon Baioreoroji Gakkai (Japanese Society of Biorheology), 15 1(2001), 29-32.

(2) Torii, R, et al, Numerical Simulation System of Blood Flow in the Cerebral Artery Using CT Image Data (in Japanese), Nihon Kikai Gakkai Ronbunshu B (Transactions of the Japan Society of Mechanical Engineers, Series B), 66 - 12 (2000), 3041-3048.

(3) Oshima, M, Image-Based Simulation of Blood Flow for Cerebrovascular Disorders, Nagare (Joumal of Japan Society of Fluid Mechanics), 21 (2002), 122-128.

(4) Ono, Y., Numerical Simulation on Blood Flow Field inside an Aneurysm at Artery Branch and in Vessels (in Japanese), Master thesis, Tohoku University, (2002).

(5) Ujiie, H., et al, Effects of Size and Shape (Aspect Ratio) on the Hemodynamics of Saccular Aneurysms: A Possible Index for Surgical Treatment of Intracranical Aneurysms, Stroke, 45 - 1 (1999), 119-130.

(6) Tanishita, K. and Fukushima, S., Micro and Macrosoopic View of Blood Flow in the Arterial Vessel, Nagare (Joumal of Japan Society of Fhid Mechanics), 21 (2002), 112-121.

(7) Roach, M. R, et al, The Hemodaynamic Importance of the Geometry of Bifurcations in the Circle of Willis (Glass Model Studies), Stroke, 3 (1972), 255-267.

(8) Liou, T.-M., et al., Pulsatile FLow Through a Bifurcation with a Cenebrovascular Anuerysm, Transaction of the ASME, Joumal of Biomechanical Engineering, 116 -February (1994), 112-118.
(9) Liou, T.-M., et al., Experimental Study of Steady and Pulsatile Flows in Cerebral Aneurysm Model of Various Sizes at Branching Site, Transaction of the ASME, Joumal of Biomechanical Engineering, 119-August (1997), 325-332.

(10) Funazaki, K., et al, Studies on Instability of Intra-Aneurysm Flow, Nihon Kikai Gakkai Tohoku Shibu Dai 37 Ki Soukai Koen Kai Koen Ronbunshu (Proceedings of 37th Annual Meeting of the Tohoku Branch of the Japan Society of Mechanical Engineers), No.021-1 (2002-3), 46-47.

(11) Kawaguchi, K, Numerical Simulation of Blood Flow near a Cerebrovascular Branch with an Aneurysm, Bachelor thesis, Department of Mechanical Engineering, Iwate University, (2003).

(12) Leuprecht, A. and Perktold, K, Computer SImulation of NonNewtonian Effects on Blood Flow in Large Arteries, Computer Methods in Biomechanics and Biomedical Engineering, 4 (2001), 149-163.

(13) Nakamura, G., Numerical Simulation of Non-Nwetonian Blood Flow near a Cerebrovascular Branch with an Aneurysm: FlowStructure Coupled Problem (in Japanese), Master thesis, Department of Mechanical Engineering, Iwate University, (2005).

(14) Ojha, M, Spatial and Temporal Variations of Wall Shear Stress within an Endto-Side Arterial Anastomosis Model, Joumal of Biomechanics, 26 - 12 (1993), 1377-1388.

(15) Keynton, R. S., et al, Intimal Hyperplasia and Wall Shear in Arterial Bypass Graft Distal Anastomoses: An In Vivo Model Study, Transaction of the ASME, Joumal of Biomechanical Engineering, 123 -October (2001), 464-473.

(16) Hayashi, K, Biomechanics (in Japanese), ed. Corona Publishing Co., 1999.

(17) Murray, C. D., The Physiological Principle of Minimum Work Applied to the Angle of Branching of Arteries, Joumal of General Physiology, 9(1926), 835-841. 